UDC 351.741(477):343.985

Svyrydiuk Nataliia,

Doctor of Juridical Sciences, Docent, Deputy Head of Scientific Research Laboratory, State Research Institute MIA Ukraine,

Kyiv, Ukraine,

ORCID ID 0000-0001-9772-1119

\title{
RATIONALE OF THE CONCEPT OF ANTI-CRIMINAL INTELLIGENCE OF LAW ENFORCEMENT AGENCIES IN UKRAINE
}

The article defines that the importance of criminal intelligence is difficult to overestimate. It is essential for the implementation of law enforcement functions.

Effective counteraction to crimes, especially its organized forms, is impossible without understanding the processes that take place in the criminal environment.

Attention is drawn to the fact that today, in connection with the entry into force of the new Criminal Procedural Code of Ukraine, operational-search activities of internal affairs bodies have lost their offensive character.

Having determined this, it is clear that the perception of the need for the formation of the Concept of criminal intelligence of the internal affairs bodies of Ukraine, the development of the Law of Ukraine "On criminal intelligence" has theoretical and practical components.

Keywords: intelligence, law enforcement, anti-criminal intelligence, criminal intelligence, intelligence information, analytical intelligence information.

Statement of problem. Combat crime is always at leading place in law enforcement activity. However, the relevance of such activities' adequacy is a fairly objective understanding of crime determination, and especially in organized forms of their actings.

Analysis of recent researches and publications. Great attention has been paid to the specific scientific and applied crime issues in the economy of Ukraine as an independent state in recent years. They are considered in dissertation researches, monographs, relevant sections of textbooks and manuals, scientific articles. In different years, they became the monographic and dissertation researches' subject of many famous scientists.

Crime prevention issues were studied in the scientists' researches of: O.M.Bandurka, V.O. Glushkov, V.V. Golina, V.K. Gryshchuk, N.O. Hutorova, L.M. Davidenko, O.M. Dzhuzhi, A.E. Zhalinsky, A.P. Zakalyuk, V.M. Kutsa, O.Ye.Korystin [1], A.M. Litvak, M.I. Melnyk, P.P. Mihailenko, M.I. Panov, V.I.Shakun and other specialists. In numerous works on Criminal law and Criminology, general issues of the crime prevention theory, prevention of certain types of crime were considered. At the same time, nowadays, crime prevention activities require fundamentally new

DOI (Article): https://doi.org/10.36486/np.2019.2.20

() Svyrydiuk Nataliia, 2019 
approaches aimed at ensuring a reliable protection of legal rights and interests of person, society and state.

Presentation of subject of the research. The joint efforts that have been made over these decades have led to successes in the criminal prosecution of organized crime groups, and some have hoped that the threat of organized crime will be overcome. As Steeer and Richards noted, “...prosecutors and investigators who were engaged in organized crime believed that if every person from especially dangerous criminals' list would be incarcerated, then only this one would paralyze organized crime and eliminate its corruption”. It is slowly, but confidently, practitioners and theorists realized that organized crime was regenerative and that is why law enforcement agencies began to focus their efforts on sources of power and the influence of organizations..." [2].

Thus, emphasis should be placed not on the individuals who are to be punished, but on the broader aspects. Law enforcement agencies should look wider - take care not only of specific offense, but also of criminal wider schemes. In 1983, Dintino and Martine pointed out that intelligence remains the only rational means of solving organized crime issue [3].

The use of intelligence also allows law enforcement agencies to obtain long-term benefits. "In order to obtain significant results, investigations should be part of a general strategy aimed not only at punishing some persons and enterprises; investigations should be based on informed understanding of organized crime issue that must be addressed, and must take into account the long-term effects of both a specific strategy and day-to-day operations on the implementation of this strategy" [4]. Thus, we must work not only for the sake of success today, but also for the purpose of long-term obtaining and preventing crime.

Intelligence products should give impetus to the fight against organized crime; but, unfortunately, this happens rarely. As a rule, efforts aimed at fighting organized crime are reported at operational-tactical level through the secret agents' using, informers and observers (physical and electronic).

All these activities are gathering of information, and many of intelligence officers consider data collection the most important thing. However, many such units operate without analysts or trained scouts capable of analyzing this important information. The information collected may be unofficially analyzed by scouts or prosecutors, but such informal analysts are not adequately trained on acceptable analytical methods that have been developed over the past few decades.

One of the main goals for which analytical intelligence information is used in operational investigations of cases related to organized crime is to identify incomes derived from criminal activity. Such a task requires an in-depth financial research and analysis. For example, bank records' analysis of enterprises controlled by organized criminals may reveal buildings, land, cars or other property that may be confiscated by law enforcement agencies, and may also detect other crimes such as concealment of income, money laundering, theft of funds, etc.

In response to organized crime strategic intelligence provides a long-term definition of objects and potential consequences of organized crime groups in the

DOI (Article): https://doi.org/10.36486/np.2019.2.20

(c) Svyrydiuk Nataliia, 2019 
jurisdiction of law-enforcement agency. It can study the evolution (and devolution) of criminal groups, as well as the scope of their influence.

For future investigations, general strategic assessments are used to identify group members and illegal activities [5]. One of the challenges faced by counterorganized crime units in the 21-st century is the increase in the number of different criminal groups and syndicates. The efforts of law enforcement agencies to minimize the negative effects of these criminal groups are hampered by the lack of reliable information about their members and activities. Therefore, the collection, systematization, analysis and compilation of such information will provide the intelligence unit with the main information for use in investigations.

The current criminogenic situation in Ukraine is a qualitatively new phenomenon both in terms of scale of criminal manifestations and in the degree of their devastating influence on the vital activity of society, the rights and freedoms of citizens. In recent years there has been a transformation of crime in our country, an increasing organized criminal groups quantity that have a strict hierarchical structure, use the latest technical means to ensure illegal activities, and counteract law enforcement. Organized criminal groups have turned into symbiosis of the shadow economy businessmen, armed groups serving them, and corrupt civil servants of different levels. It is the weakening of state control over the situation in the country, which allows criminologists to set their tone, dictate their rules of conduct, ideology, subculture, lobby for its legal, organizational and tactical decisions of legitimate power, and actively counteract law-enforcement structures. For the organization of criminal activity, they operate considerable financial resources, which are used, in particular, for bribing civil servants, law enforcement officers, attracting specialists from different sectors to create effective mechanisms, technologies, methods and schemes of committing crimes, etc. The situation is greatly worsened in connection with the intensification of aggressive manifestations of terrorism and extremism.

According to our belief, effective counteraction to crimes, especially its organized forms, is impossible without understanding of those processes that take place in criminal environment or vice versa creating the necessary conditions for documenting the facts of illegal activity, etc. In this regard, law enforcements face the need to find out the formation and existence provisions of criminal groups, their chosen mechanisms for committing crimes, role participation in this process of each party in the criminal group, the movement of shadow and certain legal financial flows that are the basis of these groups' existence or vice versa, the subject of their criminal interests, organized crime infrastructure functioning, etc. The organization of counteraction to their criminal activity requires extraction, analytical processing and use of intelligence information obtained in the course of conducting vowels and secret actions in order to timely prevent, detect and neutralize real and potential threats to the national interests of Ukraine.

The situation is also actualized by the fact that today, in connection with the enactment of the new Criminal Procedure Code of Ukraine, operative-investigative activity of internal affairs bodies has been offensive.

The essence of the offensive, which consists in the necessity of the preventive nature of operational units'actions so that, even at the early stages of the commission

DOI (Article): https://doi.org/10.36486/np.2019.2.20

(C) Svyrydiuk Nataliia, 2019 
of intentional crimes (preparation, attempt), actual data were received about the criminal intention of a person or group of persons, there was not allowed the exaggeration of previous criminal activity in disposal crime is actually ruined. Today, since the criminal proceedings' commencement, law enforcement operational units are denied the right to initiate measures aimed at establishing and exposing the perpetrators, but only acting within the scope of instructions of investigators and prosecutors. Thus, the essential arsenal of operative-investigative activities and methods remains virtually unnecessary. In addition, the current Law of Ukraine "On Operative-Investigative Activity" loses its relevance, linking the process of implementing the rights of operational units with the provisions of the Code of Criminal Procedure. We have to state that the operative-investigative activity theory has to be substantially rethought.

A comparative analysis of modern European and world practice shows that most developed countries go through a clear division of criminal procedure and activities for obtaining, extraction, analytical processing and forecasting of crime information, some crimes and those involved in them. It is precisely such activities that can be defined as anti-criminal intelligence.

The most developed network of expansion units exists in the US police, where each police unit has its own intelligence group, which, depending on its level, consists of information and analytical unit, group of operational personnel, group of special operations, experts group, operating undercover operatives' group, external and electronic surveillance groups, and logistics teams. The general purpose of the US intelligence service is to collect operational information that would ensure effective planning and implementation of anti-crime measures. This type of reconnaissance activity is called internal intelligence. Similar units were created in French Police - the brigade of search and seizure. They take active measures to study and monitor the criminal element, penetrating into its environment. The same approach has special units' organization in Switzerland. The Hungarian police have a wealth of experience in using intelligence units in the fight against crime. It has units at its disposal of carefully constrained collaborators specially trained to work in criminal sphere. In turn, the German Criminal Police and the constitution guardianship also use "under cover" officers in the criminogenic sphere, mainly for grave and particularly serious crimes' solving.

On October 2, 2012, the Seimas of the Republic of Lithuania adopted the Law "On Criminal Investigation", which replaced the Law "On Operational and Investigative Activities". With its adoption and entry into force, the counteraction to crime in the Republic of Lithuania consists of two logical components: constant reconnaissance activities and criminal procedure.

Structurally, the Law of the Republic of Lithuania "On Criminal Investigation" consists of 24 articles:

1. Purpose of the Law;

2. Basic concepts of the Law;

3. Legal basis and principles of criminal intelligence;

4. Task of criminal intelligence;

5. Protection of the rights and freedoms of person during conducting criminal intelligence;

DOI (Article): https://doi.org/10.36486/np.2019.2.20

(c) Svyrydiuk Nataliia, 2019 
6. Rights of criminal intelligence entities;

7. Duties of criminal intelligence entities;

8. Grounds for criminal intelligence;

9. Receiving information from business entities providing electronic communications and/or services, the Central Bank of Lithuania, financial enterprises and credit institutions, as well as other legal entities;

10. Use of special means of hardware, secret inspection of postal items and documents, control of postal items and withdrawals, secret control of correspondence and other communications;

11. Secret penetration of person's dwelling, service and other premises, closed territory, vehicles;

12. Tasks performed by law enforcement agencies;

13. Imitation of criminal activity;

14. Controlled delivery;

15. Observation;

16. Assistance to persons of criminal intelligence;

17. Preparation of procedural documents used for secret/ cover-up in the course of engaging in engaged activities in relation to arrested persons;

18. Use of criminal intelligence information;

19. Financing of criminal intelligence;

20. Internal control;

21. Coordination of criminal intelligence and control of legality;

22. Government control;

23. Parliamentary control;

24. Enactment.

It should be noted that the current Law of Ukraine "On Intelligence Organs of Ukraine" does not include the law enforcement operational units to the subjects of intelligence activities. At the same time, in accordance with the Law of Ukraine "On Operational Investigative Activity", "operative-investigative activity is a system of active and secret search, reconnaissance and counter-intelligence activities carried out with the use of operative and operational-technical means". This Law establishes an exhaustive list of state bodies that have been granted the right to carry out operativeinvestigative activities. In our opinion, a logical-semantic analysis of the provisions of the said Law, gives grounds for asserting that certain entities, in particular, internal affairs bodies, are granted the right to realize intelligence function.

In addition, Art. 1 of the Law of Ukraine "On Operative-Investigative Activity" stipulates that the tasks of operative-investigative activity are to search and fix facts on unlawful acts of individuals and groups, responsibility for which is provided for in the Criminal Code of Ukraine, intelligence and subversive activities of special services of foreign states and organizations in order to stop the offenses and in the interests of criminal justice, as well as obtain information in the interests of citizens, society and state security. Consequently, the legislator emphasizes the information nature of operative-investigative activity, which constitutes the essence of intelligence activities.

DOI (Article): https://doi.org/10.36486/np.2019.2.20

(c) Svyrydiuk Nataliia, 2019 
Intelligence operations of law enforcement operational units are carried out in the following areas - personal intelligence, agent intelligence, technical intelligence, analytical intelligence. In the system of the Ministry of Internal Affairs of Ukraine, intelligence functions are performed by units of the Department of Criminal Investigation, Department of Operations and Operations Department. In addition, at the tactical level, reconnaissance activities are inherent in other law enforcement operational units in terms of work. At the same time, it is etymologically correct, in our opinion, to speak about "criminal" intelligence, which emphasizes its essence and direction in combating crime.

Based on the foregoing, we believe that today it is reasonable to develop a Concept of criminal intelligence of the bodies of internal affairs of Ukraine, which should structurally consist of:

1. General provisions (statement of problem);

2. Definition of basic concepts and categories (thesaurus of concept);

3. The state of legal regulation;

4. General characteristics of the object (crime) and development forecast;

5. Purpose, task and mechanism of the concept implementation;

6 . The main ways and directions of the concept implementation;

7. Information, scientific, personnel, material and technical and financial support, etc.

The Concept purpose should be to determine the legal, organizational and tactical foundations of criminal intelligence of the bodies of internal affairs of Ukraine in order to protect individuals, state and society from crime. The elaboration of this Concept will ensure the legal basis creation for the operational units of the Ukrainian law enforcement agencies that carry out intelligence activities in the interests of criminal justice and will ensure that information security actors in Ukraine are informed of the intelligence necessary for prompt adoption of management decisions in the field of combating crime.

An obligatory element of this Concept is the drafting of the Law of Ukraine "On Criminal Investigation", introducing the relevant amendments and additions to the current legislation of Ukraine, in particular, the Criminal Procedure Code, the Laws of Ukraine "On Intelligence Authorities of Ukraine", "On the Militia", departmental normative acts, etc.

It should be emphasized that the bill should define the purpose and tasks of the criminal intelligence of law enforcements, grounds for its implementation, its legal basis and principles. It establishes the state authorities that carry out criminal investigation, these units' authorities, order of providing intelligence information and protection of criminal intelligence information, specified bill, among other things, should contain an exhaustive list of reconnaissance measures (without disclosing the tactics of their conduct). It also defines the procedure for financing and logistics, social and legal guarantees of employees of bodies and units that carry out criminal investigations and persons conducive to its implementation, guarantees of observance of legality, especially the control over the implementation of criminal intelligence, and the peculiarities of control and supervision.

DOI (Article): https://doi.org/10.36486/np.2019.2.20

(c) Svyrydiuk Nataliia, 2019 
It is believed that the perception of the necessity of forming the Concept of criminal intelligence of the bodies of internal affairs of Ukraine, the drafting of the Law of Ukraine "On Criminal Investigation" has theoretical and practical components.

First, it will promote further scientific research in the field of combat crime and revision of paradigm of operational and investigative activities.

Secondly, it will turn off the offensive, pre-emptive nature of the operational units of the internal affairs bodies in the strategic and tactical directions of combating crime.

Thirdly, it will provide a comprehensive, continuous supply of intelligence information in order to fulfill the tasks of criminal justice.

We believe that the directions of this Concept are fully in line with the directions of reforming the bodies of internal affairs of Ukraine and their legal support, the European integration course of our state.

Conclusions. The value of criminal intelligence is difficult to overestimate. It is essential for the enforcement of the law enforcement function. We must further promote its "scientific" approach, realizing, of course, that it is art that requires great analytical abilities to convert raw data into a finished product, and this product is called intelligence information. To initiate an intelligence process, you must have a criminal predicate. Perhaps even more important is the recognition that the ability to set the level of a criminal threat is of utmost importance in order to ensure that there is neither excessive nor insufficient, but a well-considered response. It is the question of threat level that seems to have led to the use of intelligence and misuse of intelligence in the history of the United States. The same reaction deserves not all criminal threats.

Accordingly, the establishment of real and fleeting or transitional threats is an art that can only be realized through careful analysis and long experience and deep knowledge.

\section{REFERENCES}

1. Anti-money laundering: international standards, foreign experience, administrative law, criminological, criminal law, criminalistic framework and financial monitoring system in Ukraine. Textbook. Ed. Korystin O. There. Kyiv: SKIF, 2015. 984 p.

2. Stier, Edwin and Peter Richards (1986) "Strategic Decision Making in Organized Crime Control; The need for a Broadened Perspective", Major Issues in Organized Crime Control. Washington, DC: National Institute of Justice.

3. Dintino, Justin and Frederick T-Martens. (1983) Police Intelligence Systems in Crime Control. Springfield, IL.

4. Goldstock, Ronald (1986) "Operational Issues in Organized Crime Control" Major Issues in Organized Crime Control. Washington DC: National Institute of Justice.

5. Peterson, Marilyn B. (1994) "Intelligence and Analysis within the Organized Crime Function" Handbook of Organized Crime in the United States, Robert J. Kelly, Ko-Lin Chin and Rufus Schatzberg, editors. Westport, CT: Greenwood Press.

DOI (Article): https://doi.org/10.36486/np.2019.2.20

(c) Svyrydiuk Nataliia, 2019 
УДК 351.741 (477):343.985

Свиридюк Наталія Петрівна, доктор юридичних наук, доцент, заступник завідувача науково-дослідної лабораторії ДНДІ МВС України, м. Київ, Україна

ORCID ID 0000-0001-9772-1119

\section{ОБГРУНТУВАННЯ КОНЦЕПЦІЇ АНТИКРИМІНАЛЬНОЇ РОЗВІДКИ ПРАВООХОРОННИХ ОРГАНІВ В УКРАЇНІ}

У статті доведено, що значення кримінальної розвідки переоцінити важко. Вона є суттєво важливою для виконання правоохоронної функції.

Ефективна протидія злочинам, особливо її організованим формам, неможлива без розуміння тих процесів, які відбуваються у злочинному середовищі.

Акцентовано увагу, що сьогодні, у зв'язку з набранням чинності новим Кримінальним процесуальним кодексом України, оперативно-розшукова діяльність правоохоронних органів України втратила наступальний характер.

Компаративний аналіз сучасної європейської та світової практики засвідчує, що більшість розвинених країн рухаються шляхом чіткого розгалуження кримінально-процесуальної діяльності та діяльності з отримання, добування, аналітичного оброблення та прогнозування інформації про злочинність, окремі злочини та осіб, що до них причетні. Саме таку діяльність можна визначити, як антикримінальну розвідку.

Акцентовано, що на сьогодні обгрунтованим є розроблення Концепції кримінальної розвідки правоохоронних органів України. Розроблення цієї Концепції забезпечить створення правових основ діяльності оперативних підрозділів правоохоронних органів України, які здійснюють розвідувальну діяльність в інтересах кримінального судочинства та забезпечать інформування суб'єктів забезпечення національної безпеки України розвідувальною інформацією, необхідною для оперативного прийняття виважених управлінських рішень у сфері протидії злочинності.

Напрями означеної Концепції повною мірою збігаються з напрямами реформування правоохоронних органів України та їх правового забезпечення, Свроінтеграційним курсом нашої держави.

Наголошено, що законопроект “Про кримінальну розвідку” має визначати мету і завдання кримінальної розвідки правоохоронних органів, підстави для іï здійснення, її правову основу та принципи.

Вбачається, що сприйняття необхідності формування Концепції кримінальної розвідки правоохоронних органів України, розроблення Закону України “Про кримінальну розвідку” мають теоретичну та практичну складові.

Ключові слова: розвідка, правоохоронні органи, антикримінальна розвідка, кримінальна розвідка, розвідувальна інформація, аналітична розвідувальна інформація.

Отримано 06.06.2019

DOI (Article): https://doi.org/10.36486/np.2019.2.20

(c) Svyrydiuk Nataliia, 2019

Issue 2(44) 2019

http://naukaipravoohorona.com/ 